\title{
The Disembodied Librarian in the Digital Age
}

\section{Charles Martell}

\begin{abstract}
Four profound historical discontinuities - time and space, mind and body, real and virtual, and humans and technology-are reaching critical thresholds as we enter the twenty-first century. Existing within multiple environments (technological, social, and cultural), these discontinuities are seldom acknowledged, but their influence on the future of our institutions is incalculable. An awareness of them will assist librarians in (1) creating a new virtual space for libraries as physical space becomes less important, (2) adapting to states of disembodiment caused by roles deeply embedded in virtual environments, and (3) developing the new value-added services necessary for survival in this millennium. The discussion of these historical discontinuities will continue in the March issue of $C \& R L$, in which they are related to new ways of being and thinking about the future of librarians and libraries.
\end{abstract}

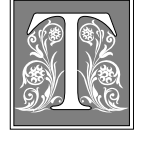

he Age of Enlightenment lives on. ${ }^{1}$ Reason as employed by science and the idea of indefinite progress are two of the building blocks of the Enlightenment. There have been other "ages"; some no longer seem relevant. Whatever happened to the Atomic Age or the Space Age, for example? The first and second Industrial Ages are among the most frequently cited. The Information Age has been around since the early 1960s. The Knowledge Age had a brief appearance, but the realities of war and despotism in the twentieth century may have made it difficult for knowledge to win out over information. At least information seems to have held the age field against television, although it was probably a close call. Knowledge has lost out in librarianship as well. Instead, bits and bytes have the upper hand.
The Digital Age people must know something. Maybe they know that ages come and go. Maybe they also know that overuse and misuse have rendered the term age relatively meaningless. In the twentieth century, we became masters at manipulating language and adjusting its symbolic value. Accuracy of meaning is no longer an indicator of appeal. Television has helped. Today, an age may not last as long as a popular TV series. Years ago, we tried to keep our ages separate. They did not seem to run concurrently. Has the Digital Age superceded the Information Age? Perhaps the Information Age can be promoted to a revolution, thereby making room for the Digital Age. No redundancy allowed. Our minds are clear again. At least this author's mind is. 
The death of Immanuel Kant, in 1804, may have marked the end of the Age of Enlightenment, but many of the Enlightenment's principles still guide the actions of people today. ${ }^{2}$ For example, the influence of the sciences grew dramatically in the 1800s, although the discovery of the irrational has been cited as the most singular feature of the century. ${ }^{3}$ Rejection of realism and exploration of the unconscious were notable themes in the arts. The idea of unlimited progress may have worked in the first Industrial Age, but during the twentieth century its appeal has greatly diminished. Humanity's ravages against the natural environment and wars of mass destruction influenced this shift in thinking.

The idea of unlimited progress may have worked in the first Industrial Age, but during the twentieth century its appeal has greatly diminished.

Positivism flowed out of the Enlightenment. Henri, comte de Saint-Simon, first used the term to describe the extension of the scientific method to philosophy. ${ }^{4}$ Auguste Comte narrowed the term's meaning by stating that the only valid knowledge comes from science and that facts are "the only possible objects of knowledge." ${ }^{5}$ According to the Encyclopedia of Philosophy, "positivism ... denies the existence or intelligibility of forces or substances that go beyond facts and the laws ascertained by science. It opposes any kind of metaphysics and, in general, any procedure of investigation that is not reducible to scientific method." ${ }^{6}$

Some authors have suggested that positivism is the tacit philosophy of librarianship. ${ }^{7}$ Gary P. Radford and John M. Budd questioned "a prevailing positivist orientation toward knowledge in order to foreground different views of knowledge that have the potential of providing alternative frames of reference from which to recreate the perceived reality of the library experience." ${ }^{8}$ Budd's goal is "to shift, first thought, then discourse, then research, by initiating a questioning of assumptions and purposes." ${ }^{\prime 9}$ These authors' indictments of, and challenges to, the profession have gone largely unanswered. ${ }^{10}$ This serves to reinforce the accuracy of their observation that the profession lacks a viable intellectual foundation. ${ }^{11}$

This author likes the ideals of the Enlightenment but would blend the sciences and the humanities, rather than favor the former over the latter. Edward O. Wilson uses the word "consilience" to describe this union. ${ }^{12}$ By mid-twentieth century, according to Wilson, hope for a unification of knowledge with the aid of science was all but erased. ${ }^{13}$ The "failure to unify" pattern has been repeated throughout history. The cause is simple. When we are unable to accept the values accompanying a particular event, we ignore them. Occasionally, we attempt other remedies. Sometimes the discontinuity is resolved because the new value system is faulty and fades away. Sometimes the value system changes or we change as time passes. What was formerly alien may become commonplace.

The discontinuity or symmetry breaking can be of epic proportions. In Beyond Geography, Frederick Turner found the heaven and earth, animals and humans, body and soul discontinuities so typical of western civilizations missing from "the generative principles of archaic myths." ${ }^{\prime 14}$ These discontinuities are familiar themes in literature. They can be illuminating as Peter Hoeg demonstrates in a comparison of the Inuit of Greenland and the Danes of Denmark. The heroine of Hoeg's novel Smilla's Sense of Snow admires the Inuit "because of their ability to know, without a shadow of a doubt, that life is meaningful. Because of the way, in their consciousness, they can live with the tension between irreconcilable contradictions, without sinking into despair and without looking for a simplified solution. Because of their short, short path to ecstasy. Because they can meet a fellow human being and see him for what he is, without judging, their clarity not weakened by prejudice." ${ }^{\prime 15}$ 
Commenting on the theme of discontinuity in Charles Radding's A World Made by Men: Cognition and Society, 400 1200 (Chapel Hill: University of North Carolina Press, 1985), Morris Berman noted that "certain cognitive shifts can occur in a civilization that are so profound that there seems to be almost no mental continuity between one epoch and the next. This is not a question of one age having a different set of ideas from the next, or even a different set of beliefs or values. It is rather a total revolution in perception, a whole shift in the way reality presents itself to the eyeball and the brain. The shift from magic to science, from a living world to a dead one, such as occurred during the Scientific Revolution, is such a shift because there is, for example, nothing an alchemist and a chemist can meaningfully say to each other."16

The common view among librarians is that the changes in their profession are following an evolutionary, rather than a revolutionary, pattern. From this perspective, relatively few adaptations will be required of them. However, this vision is too narrow. It overlooks fundamental dislocations occurring throughout the world. These will alter what it is to be human, both conceptually and consciously. A new ontology must be created and nurtured. Similar dislocations have been found in other stages of human history. Indeed, two technologies-writing and printing-were extremely destructive to the values of earlier societies.

Plato did not like the idea of writing. Would it not destroy memory? Would the mind not suffer? "This discovery of yours will create forgetfulness in the minds of those who learn to use it; they will not exercise their memories, but, trusting in external, foreign marks, they will not bring things to remembrance from within themselves."17 Plato asked the wrong questions. He assumed we wanted to use our minds for the purposes he valued. Libraries are a replacement for Plato-type minds. After quoting Socrates' objections to writing, James
J. O'Donnell argued that "oral communication predisposes one toward collaboration and cooperation, writing is onesided and puts new power in the hands of the writer."18

In the late fifteenth century, Filippo di Strata noted that the world had got along perfectly well for six thousand years without printing and had no need to change. ${ }^{19}$ The printing press and the Enlightenment went hand in hand, although centuries elapsed before the book as it is now known made an appearance. ${ }^{20}$ Today's libraries have their genesis in this powerful union. Unfortunately, we are very likely to overlook the momentous and negative impact of the invention of printing on the world's oral cultures.

It is not easy to adapt to a change that impacts our system of values. The consequences can be profound. We may lose sight of who we are. We may lose our sense of purpose and meaning. Soren Kierkegaard wrote: "Be with what is so that what is to be may become." In First You Have to Row a Little Boat: Reflections on Life and Living, Richard Bode responded to Kierkegaard: "It was sound advice, but before I could 'be with what is,' I had to give up what was and could be no moreand that, as my friend well knew, is a painful undertaking for which there is no known palliative." 21

Holding on to ideals is good if what we hold on to is vital and valid. Far too often, however, we do not hold on at all. Values frequently become ghostlike, put on and taken off as if it were Halloween. Worst of all, we have poor memories. Plato was right. Even with libraries, it is difficult to keep track. We hold on to misleading values, meaningless values, and pseudo values. We know what we are doing in the present but forget too quickly the events of yesterday. We plan for the future based on today and with an idealized or flawed view of the past. Without an accurate knowledge of the past and its lessons, we will be unable to construct a full range of scenarios of potential future events. In Nineteen Eighty-Four George Orwell's "The Party" states: ${ }^{22}$ 
Who controls the past controls the future. Who controls the present controls the past.

Do we need a philosophy? Budd and Radford think we do. But James Zwaldo does not; he believes "we're confused enough already." ${ }^{23}$ Are we positivists? Budd and Radford say we are. According to Michael K. Buckland, library science must satisfy the following criteria to qualify as a science: ${ }^{24}$

- The subject area and the phenomena to be studied must be specified.

- The basic descriptive concepts must be clarified.

- The fundamental quantitative laws peculiar to the subject must be developed.

- A theory able to relate a multiplicity of phenomena must be developed.

One could conclude that we are positivists without a science. Postmodernists would understand this contradiction. Contradiction was a symptom of life in the twentieth century.

The image(s) being formed will change constantly as new information allows the reader to increase his or her understanding and intuitive connection to issues that are confounding, upsetting, and mindbending.

Some of us are in the process of actively constructing the digital library for the Digital Age. Bits and bytes will define us in the future just as books and buildings have defined us in the past. ${ }^{25}$ We are lost. Once again, we are placing our identity in things not in our expertise. We need to remake ourselves to avoid becoming obsolete. We need to create a range of services unthinkable in the twentieth century, but mandatory in the twenty-first century, if we are to provide society with the value-added services it will need from its professionals.

The concept of the librarian has grown weak and brittle as we have stood in the shadow of the library. An old story, an obsolete structure, and a valueless digit. By exploring more extensively the context of our lives, personally and professionally, we may begin to understand the nature of the path we must take toward a more enlightened future. If we do not, it is OK: ${ }^{26}$

and the future

will be no less vast without us.

\section{Ekaterina Iosifova}

This author uses a barometer to judge the value of the direction in which libraries are moving. Movement toward higher, life-enhancing values represents an increase in value-added services. Movement toward lower, thing-enhancing values represents a decrease in value-added services. A downward movement creates an uncomfortable feeling. T.S. Eliot gave this barometer to us. Life, the highest value, is at the top of the scale; information is at the bottom. This author has taken the liberty to update Eliot by adding a new last line (in italics), believing that Eliot would approve of the logic: ${ }^{27}$

- Where is the Life we have lost in living?

- Where is the wisdom we have lost in knowledge?

- Where is the knowledge we have lost in information?

- Where is the information we have lost in digits?

This author's barometer indicates that movement from information toward digits will create a lower value-added service for students and faculty.

The stage now is set for a viewing of four extraordinary discontinuities. Each has been a subject for philosophers and other thinkers throughout the centuries. Advances in computer science and biology provide added interest. The four themes are time and space, mind and body, real and virtual, and humans and technology.

No one can provide a picture of the future. This author can only offer pieces, but the pieces are significant. Some readers may not have thought a lot about them, but other readers have. The method is re- 
ductionist. The pieces are like those in a puzzle, but the reader will have to shape them to his or her specific reality and values. It is hoped that the reader can use them to build something. He or she should think of the pieces as malleable. The image(s) being formed will change constantly as new information allows the reader to increase his or her understanding and intuitive connection to issues that are confounding, upsetting, and mind-bending. Some of the pieces will be colored by the manner of presentation and by what is included or excluded in this discussion. This may help the reader see patterns or relationships not previously discovered. Personally, the author does not yet have a picture but, rather, an instinct or gut feeling. The author has a little bridge, a connection, for linking things together.

In the continuation of this discussion in the March issue of $C R \mathcal{E} L$, information from the four themes will be distilled in order to consider new ways of being. A section on libraries in the future will follow. In these sections, an effort will be made to show how traditional thinking about libraries and traditional ways of thinking generally may have to change. Students and faculty are telling librarians things all the time. Many connect their information needs to their lives. We do not see it. We do not hear them. We are creating and maintaining structures for them, and we are frequently doing it from the inside out starting at the bottom of the barrel with information or digits. If we open our minds as fully as possible without preconceptions, perhaps we will do better. As the twenty-first century progresses, students and faculty will be changing in ways that parallel our own changes, but to hear we will have to understand a new language and to minimize the filters and ideologies that language imposes on our understanding: ${ }^{28}$

And the word, an umbilical cord clinched like a noose around the facts of life, lived or merely dreamed

\section{Time and Space}

\section{Time}

We often take time for granted. Time is a subject for astrophysicists and the good people in Teddington, England, who maintain a cesium-beam atomic clock. They adjust time for us. We do not have to trouble ourselves. Oh yes, there is daylight savings time or its reverse and the replacement of batteries or cells. The author's favorite way to relate to time is through observations of the sun and the moon.

Jeremy Rifkin does not take time for granted. In Time Wars: The Primary Conflict in Human History, he discusses the human race's primary time-allocating devices: biotic rituals, astronomical calendars, clocks and schedules, and computer programs. ${ }^{29}$ "With the introduction of each new device, the human species has detached itself further from the biological and physical rhythms of the planet. We have journeyed from close participation with the tempo of nature to near isolation with the earth's rhythms." ${ }^{30}$

Three Seconds of Eternity is a superb book of photographs taken by Robert Doisneau in his hometown of Paris, France. ${ }^{31}$ He chose the title to reflect the elapsed time in which photographers live and in which their fame may be forever secured if those three seconds are well spent. Three seconds would allow Doisneau or any photographer to take three hundred photographs at $1 / 100^{\text {th }}$ of a second per photograph.

Computers move beyond seconds to nanoseconds. The time interval required to snap one's fingers is equivalent to 500 million nanoseconds..$^{32}$ How do we relate mentally and psychologically to dimensions of time that "lie between the dimensions of human experience: fractal dimensions"? ${ }^{33}$ The answer is probably quite simple. We cannot-at least, not yet. Rifkin calls the new time associative rather than linear. "It is a stepchild of psychological consciousness, just as the concept of linear time was a stepchild of historical consciousness... Time loses the independent status it enjoyed during the 
clock culture. Time is now a resource, not a reference point." ${ }^{34}$

According to Scott Bukatman, "The digital, processed graphics of electronic technology ... produce a constant mutation divorced from the metamorphoses of human time and experience. The weakened representational function of these decorative and malleable images produce little sense of permanence, history, or bodily investment at all... The screen operates as the frontier between the two realities, physical and electronic. It is a space without center or ground, and with only a vector-graphic simulation of perspective (too crisp, too perfect) to guide a human eye that has suddenly become distinct from its corporeality, its spatiality, its temporality, and its subjectivity." 35

This discontinuity with time is not a recent phenomenon; however, the move beyond the dimensions of human experience is. But other factors are complicating the situation. Lance Olsen suggested that as we move into the realities of cyberspace we "move from the realm of chronos to that of kairos, from a prosaic geography registering realistic chronology, logic, and stability to a transcendent one registering fantastic timelessness, alogic, and possibility. ${ }^{\prime 36}$ How we adapt to the new time dimensions will influence our workplace and the services and products provided therein. Workplace consultant John Kao has found that "design must accommodate the increasingly projectoriented, temporal quality of work. The idea of lifelong work, of going to a physical location and doing one thing, is gone." 37

\section{Space}

A graphic representation of data abstracted from the banks of every computer in the human system. Unthinkable complexity. Lines of light ranged in the nonspace of the mind, clusters and constellations of data. Like city lights, receding ... ${ }^{38}$

William Gibson
The word cyberspace was first used in William Gibson's 1984 novel Neuromancer. Since then, the meaning of the term has been altered and most often is used to depict the Internet. Gibson's vision is bold. His metaphor is powerful. It dwarfs our common perceptions of the Internet. His understanding of cyberspace was formed by reading reports from MIT computer labs and watching kids playing video games at the arcades on Granville Street in Vancouver. "These kids clearly believed in the space these games projected." ${ }^{39}$

\section{The chasm between his images of the future and the visions of the future as depicted in library litera- ture is enormous. And this is worrisome.}

Marie-Laure Ryan believes cyberspace became a compelling and enchanting "metaphorical space when the idea of traveling information was replaced with the idea of a traveling user." 40 Frances Cairncross confronted the same theme in The Death of Distance: How the Communication Revolution Will Change Our Lives. ${ }^{4}$ The concept of the traveling user parallels the popular imagery about the Internet widely circulated in the media and library literature. In California, one surfs the Internet; in West Virginia, one mines it. The terminology may change from state to state and nation to nation, but the meaning is the same. We become explorers and adventurers without moving from our chairs. What moves? Our minds do.

The image of cyberspace depicted by Gibson qualifies as a "specialized mediation" in Margot Lovejoy's sense of the phrase: "We can only see the world by forming a picture through various specialized mediations ... We now lack a convincing vision." 42

Lovejoy's reference to specialized mediations strikes a responsive chord with this author, who arrived at an intuitive and compelling, but only vaguely conscious, image of cyberspace while read- 
ing two books lent to him by his son during a trip together in the Italian Hill Country a few summers ago. For brief moments this author saw cyberspace-and understood it. A bridge had formed, however narrow. Coincidentally, both books, Virtual Light and Idoru, were written by Gibson. ${ }^{43}$ Further reading about cyberspace dragged this author into a totally unanticipated range of topics, including postmodernism, the space-time continuum, possible worlds, virtual reality, and many other themes that helped form the substance of this article. This mental bridge has not grown wider, although this author has used it frequently to revisit the images of cyberspace he once experienced. The chasm between his images of the future and the visions of the future as depicted in library literature is enormous. And this is worrisome. The hope is that some of the information discussed in this article will assist others in building their own mental constructs of a different world.

The culture emerging around the concept of cyberspace recognizes that society has, in Bukatman's words, "passed beyond the spatio-temporal experience of its citizens." 44 Bukatman also has suggested that "in the context of cybernetic disembodiment, rooted in nanoseconds of time and imploded infinities of space, cyberspace addresses the overwhelming need to reconstitute a phenomenal being." ${ }^{45}$ The dual themes of passing beyond our everyday spatio-temporal experiences and attempting to reconstitute ourselves through the agency of cyberspace fascinate literary critics and others who believe that literature often provides the narratives by which we discover ourselves. A recent book by Thomas Disch described the ways that science fiction has contributed to this process of discovery. ${ }^{46}$

Some of the characters inhabiting Gibson's textual space and cyberspace appear to be striving, almost paradoxically, perhaps subconsciously, to reconnect themselves to a primitive self by surmounting the demands made on them by the very technologies they operate so masterfully. Ronald Schmitt suggested that "if any pattern emerges from Gibson's mythologizing of technology and humans' relationships with technology, it is the emphatic denial of the mechanistic image of humans in a technological culture. The use of primitive mythic entities and practices like ghosts, demons, sacrifice, the shaman, etc. is clearly a means by which Gibson can humanize these unhuman, cold, and impersonal technological forces that increasingly challenge the boundaries between the corporeal and the mechanical." 47

Outer space and inner space, psychological space and physical space, and other space sets still interest us, along with the more recent phenomenon of cyberspace.

In his article "Smooth Spaces and Rough-edged Places: The Hidden History of Place," Edward S. Casey states that in the 1600s, "the idea of place was beginning to disappear from philosophical and scientific discourse." 48 It was replaced by the idea of space. Some went even further and suffered the consequence. Giordano Bruno was burned at the stake in 1600 for suggesting that there was "not just infinite space but an infinite number of worlds in such space." ${ }^{\prime 49}$ According to Casey, "it is difficult to deny some significant connection between the demise of place as a viable philosophical category and the rise of the alienated modern subject. The alienation first articulated by Pascal and then codified and rationalized by Kant is, I would suggest, an alienation from place at least as much as it is an alienation from abiding metaphysical and religious ideas and ideals." ${ }^{50}$ Kant's view was that the "phenomenal self, the only self we know, is radically unemplaced." ${ }^{51}$ For different reasons, Freud came to a similar conclusion: man is not a master in his own house. He believed that the traditional view of self as whole and undivided was undermined by the presence of an unconscious.

So, humans are not supposed to be in place but, rather, in space. Displaced by 
Kant. The public ignores Kant. Disembodied by Freud. The public uses what it wants of Freud and discards the rest. The intellectual discoveries of Kant, Darwin, Freud, and Einstein, among others, made centuries-old metaphysical and religious beliefs obsolete. They destroyed the foundations of the old, but the only reasonable substitute seemed to be science itself, science as de facto religion. This was unacceptable. So the public largely maintained its old beliefs, isolating them from objective fact and the clear view of reason, while simultaneously accepting science not as a substitute for religion but, rather, in addition to the public's other prescience beliefs. Life became more complicated, and alienation became a fact of life. The aggregate impact of these discontinuities is unclear, but they have affected many people. Daily, millions of Americans stream into the offices of therapists. The reasons sometimes relate to the very kinds of unresolved issues mentioned above. Librarians are not exempt. Writers in the twentieth century have been very attentive. Many have commented on the absence of place as a concept in scientific discourse, the absence of self, and the uncertainties surrounding truth in mediated societies.

\section{Mind and Body}

Major figures of the Enlightenment recognized that humans were displaced by the empowerment of the mind. "According to Saint-Simon, men now lived in a critical epoch because scientific progress, by destroying theological and metaphysical doctrines, had eliminated the foundation of social organization of the Middle Ages." ${ }^{2}$ Saint-Simon was wrong. Science destroyed the agrarian way of life, not theology. Theology merely jettisoned its previous claims to reason. Doctrines of faith were dusted off and re-crafted as theology recreated itself. A simpler interpretation is that religion as a way of life, not as dogma, always had the greatest appeal among the people.

Maurice Merleau-Ponty maintained that the unitary truth of the Enlighten- ment as represented by Descartes's cogito was insufficient to ground human experience. ${ }^{53}$ If we do not have a unitary truth upon which to ground human experience, what do we have? This question becomes critical to Merleau-Ponty in a postmodern era when the reality of self is arrayed against multiple selves and multiple realities. ${ }^{54}$ In From Text to Hypertext, Silvio Gaggi depicted the cogito as "both dispersed and enlarged, not by a challenge of philosophy or theory, but by the subject's experience in a decentered network that threatens to eclipse the 'individual' subject that understands itself as physically embodied and clearly localized in space and time." 55

Bukatman stated: "The duality between mind and body is superseded in a new formation that presents the mind as itself embodied. The body, here, exists only in phenomenological terms: it perceives and it moves (a reductive and utopian version of Merleau-Ponty's model of subject-construction, which eliminates the mortal limitations of a physical body). Through the construction of the computer itself, there arises the possibility of a mind independent of the biology of bodies, a mind released from the mortal limitations of the flesh. Unlike the robot forms of the modernist era, wherein a mechanical body substituted for the organic, the invisible processes of cybernetic information circulation and electronic technology construct a body at once material and immaterial-a fundamental oxymoron, perhaps, of postmodernity." ${ }^{\prime \prime 6}$

Frederic Jameson was equally provocative: "This latest mutation in spacepostmodern hyperspace-has finally succeeded in transcending the capacities of the individual human body to locate itself, to organize its immediate surroundings perceptually, and cognitively to map its position in a mappable external world ... this alarming disjunction point between the body and its built environment ... can itself stand as the symbol and analogue of that even sharper dilemma which is the incapacity of our minds, at least at present, to map the great global 
multinational and decentered communicational network in which we find ourselves caught as individual subjects." 57

The inner space of the human psychology no longer offers the same place of refuge. Jacques Lacan and his followers view the ego as an illusion. If there is no core self, what do we experience? The answer is probably whatever we want "as the 'I' can be likened to something we create with smoke and mirrors." ${ }^{58}$ A central belief uniting many diverse thinkers is that we construct our own reality. Each of us shifts the mirrors around for myriad reasons to deal with the environment surrounding us.

The dissolution of who we are has not happened abruptly. Television and other media have been undermining us for years. "Television, video cassettes, video tape record/players, video games and personal computers all form an encompassing electronic system whose various forms 'interface' to constitute an alternative and absolute world that uniquely incorporates the spectator/user in a spatially decentered, weakly temporalized and quasi-disembodied state. ${ }^{\prime 59}$

The impact of television on society and culture has been well documented. Its negative features are odious, but the smoke and mirrors wielded with the subtlety and the power of a theology, a commercial theology, minimize the distractions and serve to protect the self from a dangerous realization. We authenticate ourselves via television. A recent publication entitled Glued to the Set has a provocative subtitle, The 60 Television Shows and Events That Made Us Who We Are Today. The dust jacket drives the point home with the skill of a Rocky Horror Show: "Television is so much a part of us that we breathe it like air. We also take it for granted. Yet its sitcoms, technie-thrillers and laugh tracks are the life blood of the baby boom generation and the ongoing cultural mindset of our nation." ${ }^{60}$ Truth is irrelevant in front of the tube.

According to Sherry Turkle, "the computational models of mind that dominated academic psychology [fifteen years ago] were modernist in spirit: Nearly all tried to describe the mind in terms of centralized structures and programmed rules. In contrast, today's models often embrace a postmodern aesthetic of complexity and decentering. Mainstream computer researchers no longer aspire to program intelligence into computers but expect intelligence to emerge from the interactions of small subprograms. ${ }^{\prime 61}$ The implication is that computers will create their own intelligence.

\section{The psychological consequences of being disembodied are likely to become more severe as technological innovations cause increased cultural and societal fragmentation.}

Princeton physicist Freeman Dyson imagined further steps in the process of evolution: "Humanity looks to me like a magnificent beginning but not the last word." ${ }^{62}$ Would computer intelligence qualify as the next word? In Blood Music, science fiction writer Greg Bear presented "the passage beyond the flesh-beyond the human-as a significant and legitimate evolutionary step. The human is not reified as an unchanging and finished product; instead, the work is concerned most exclusively with metamorphosis, transformation, development, and evolution." 63

An example of this type of thinking in the real world made its appearance at Paul Evan Peter's 1992 LITA President's Program. One of the speakers was Hans Moravec, a leading mobile roboticist from Carnegie-Mellon. A pioneer in artificial intelligence, Moravec believed "an individual brain could be entirely imported into a computer program and supercopied. The human body would become superfluous. When the body died, the program could be housed in a robotic body, and the individual's consciousness could live forever." ${ }^{\prime 4} \mathrm{He}$ also believed that "over time, more compact and faster ways of using space and matter will be invented and used to restructure the cyberspace, effectively increasing the amount of computa- 
tional spacetime per unit of physical spacetime." 65

Some take the idea of disembodiment rather lightly. Morris Berman does not. He believed that we are alienated from our bodies as a result of developments reaching back thousands of years. Moreover, he was highly critical of the "Western academic understanding, including philosophy and anthropology as well as history ... that the body has nothing to tell us, has no knowledge or 'information'; that for all practical purposes, it isn't even there." ${ }^{\prime 66}$ The prospects for a unification of mind and body (reembodied or reconstituted) are not favorable at the present time. The psychological consequences of being disembodied are likely to become more severe as technological innovations cause increased cultural and societal fragmentation.

\section{Real and Virtual}

In an article entitled "Back to Chaos," Wilson wrote: "In his 1941 classic Man on His Nature, the British neurobiologist Charles Sherrington spoke of the brain as an 'enchanted loom,' perpetually weaving a picture of the external world, tearing down and reweaving, inventing other worlds, creating a miniature universe." ${ }^{\prime 67}$ Most people have a relatively fixed view of reality and their place within it. Changing cosmetics is one thing; changing our understanding of reality represents danger and threat. Historically, we have fortified ourselves against such intrusions. Will we use the loom as we have in the past, or will we use it differently? Will we fortify ourselves? The brain may take a second look at its body, a body irrelevant in cyberspace. Jack G. Voller called this slipping "the shackles of body and time." 68

Epic shifts are occurring. Vaclav Havel, president of the Czech Republic, addressed this theme in a speech at Independence Hall on July 4, 1994. He said: "The world of our experiences seems chaotic, disconnected, confusing. There appear to be no integrating forces, no unified meaning, no true inner understand- ing of phenomenon in our experience of the world. Experts can explain anything in the objective world to us, yet we understand our lives less and less. In short, we live in the postmodern world, where everything is possible and almost nothing is certain." 69

Sherry Turkle explored one of the consequences of a world in disorder: "When the individual loses confidence in his ability to understand the world around him, when he feels split between private and public identities, and when social 'recipes' no longer offer him a sense of meaning, he is apt to become an anxious consumer of reassurances about his 'authentic' subjectivity, his hidden 'inner life,' and his deepest interpersonal experiences. People seem to respond to what Max Weber described as the 'world's disenchantment' by becoming fascinated with the mysteries of their interior alchemy."

The phenomenon Turkle described may be observed most often when the significance of social and cultural institutions is questioned. More and more people seem to believe that our institutions lack "any particular, transcendent validity." This belief, one of the greatest of all heresies according to Berman, may cause others to deny, ignore, or remove the source of the criticism. ${ }^{71}$ Some people will seek new solutions. The postmodernists have been successful in pointing out what is wrong. Problem identification is a crucial first step in creating a new consciousness. The postmodernists do not provide answers, and they have been faulted for this. The meaning of postmodernism itself has become nebulous and may merely mean "fairly recent."72 "Fairly recent" sounds good. Nevertheless, comment on the meaning of postmodernism is warranted because many of the themes in this article reflect a postmodern perspective.

Mohamed Zayani described postmodernism's core features as follows: "Broadly speaking, postmodernism signals a reaction against the very foundations of modernism. It entails, among other things, an undermining of positivistic science, a challenge to objective 
knowledge and to rationality, an incredulity towards meta-narratives as totalizing discourses, a critique of absolute truths, and a questioning of the possibility of envisaging a unified history." ${ }^{173}$ However, modernism remains dominant as a political and economic force.

Early Greek philosophers posed the question, What is reality? And this question continues to intrigue us. In the twentieth century, television is most frequently cited as the major technological influence distorting reality and replacing it with something different. Every day, millions of people are transported to a different reality in their own living rooms. The talk shows and daily soap operas provide a life as meaningful to many people as their own. Jean Baudrillard described this type of reality shift as a four-stage process. First, the image is "the reflection of basic reality." At this stage, we believe the image is a sign of the truth. Second, the image "masks and perverts a basic reality." Third, the image "masks the absence of a basic reality." And fourth, the image "bears no relation to any reality whatever; it is its own pure simulacrum." ${ }^{\prime 4}$

In his 1967 manifesto entitled Society of the Spectacle, Guy Debord examined the "immense accumulation of spectacles" in postindustrial societies. ${ }^{75}$ Particularly noteworthy attributes of the spectacle are the loss of representational truth and "the implosion of the medium and the real in a sort of nebulous hyperreality." ${ }^{176}$ If we hope to hold on to reality, what do we grasp? The media cannot be relied on. In Glued to the Set, Steven D. Spark observed that one of the major ideologies emanating from the television set relates to freedom-the freedom to acquire. Consumerism is the preeminent value; all else is secondary. "Shows which implicitly dampen the spirit of consumerism-say tragedies-have less of a chance of making it to television. ${ }^{\prime 77}$ Corporate sponsors want a happy viewer in order to increase the likelihood of a positive response to their advertisements.

As professionals who deal with information daily, librarians might ask what happens to the information delivered through television. Baudrillard said that "information devours its own content."78 Arthur Schlesinger Jr. seemed to agree: "The rise of the electronic media has drain[ed] content out of [political] campaigns." 79 Alvin Toffler broadened the impact: "The result of this image bombardment is the accelerated decay of old images, a faster intellectual through-put, and a new, profound sense of the impermanence of knowledge itself." ${ }^{\prime 80}$

The simulation of reality as distinct from its representation is becoming a major growth industry. Prospects for the future are extraordinary. "In the story of constructing identity in the culture of simulation, experiences on the Internet figure prominently, but these experiences can only be understood as part of a larger cultural context. That context is the story of the eroding boundaries between the real and the virtual, the animate and the inanimate, the unitary and the multiple self, which is occurring both in advanced scientific fields of research and in the patterns of everyday life." 81

The Internet, medicine, and military offer examples of simulation and its impact.

\section{Internet}

The Internet examples are taken from Turkle's Life on the Screen. Internet users in multi-user domains (MUDs) frequently think of their experiences in cyberspace (or electronic space) as real.

An eleven-year-old girl who uses computers regularly and belongs to a chat group in an MUD has "built a room she calls a condo. It is beautifully furnished. She has created magical jewelry and makeup for her dressing table. When she visits the condo, she invites her cyberfriends to join her there, she chats, orders a virtual pizza, and flirts." 82

"When people can play at having different genders and different lives, it isn't surprising that for some this play has become as real as what we conventionally think of as their lives, although for them this is no longer a valid distinction." ${ }^{13}$ 
A fifty-year-old Caltech graduate likens the Internet to "a brain, self-organizing, nobody controlling it, just growing up out of the connections that an infant makes, sights to sounds, ... people to experiences ... Sometimes I'll be away from the Web for a week and a bunch of places that I know very well will have 'found' each other. This is not an engineering problem. It's a new kind of organism. Or a parallel world. No point to analyze it. No way you could have built it by planning it." ${ }^{\prime 84}$

\section{Medicine}

Rick Satava, a laparoscopic surgeon and project manager with the Advanced Research Project Agency, said that "what we used to think of as blood and guts are just bits and bytes." 85

In his article "Surgery in Cyberspace," Gary Taubes reported that "researchers across the country are pursuing a new technology in which a human surgeon manipulates surgical instruments that appear to extend into a three dimensional image of a patient's body while computers perfectly translate the surgeon's movements into the parallel actions of a machine [a microrobot] wielding real surgical tools inside a flesh-and-blood patient." 86 The surgeon is in virtual space and the microrobot is in real space operating on the patient. Seemingly, we are becoming just as connected to our machines as we are to our own eyes and ears. This aspect of the human-machine connection is discussed in the following section.

In What Will Be: How the New World of Information Will Change Our Lives, Michael Dertouzos, director, MIT Laboratory for Computer Science, alleged that the second major explosion in the Information Marketplace will be health care. ${ }^{87}$ The entertainment transformation has already begun. The soaring cost of medical care is a major incentive for these efforts. Robotic and augmented-reality surgery are reviewed. ${ }^{88}$

\section{Military}

War is a serious endeavor with critical consequences. The military has used virtual tools for well over a decade, and the use of simulation in the training of pilots is well documented. Simulated training has been extended to tanks. "The players, who are tank commanders, operate inside a mockup of the interior of a tank. Their view of the battlefield is a computergenerated display. But in a devilish mix of reality and virtuality, some commanders on Simnet are actually riding in real tanks out on the desert, miles away. The commanders on the tank simulators do not know if the tanks they see on their monitors are real or virtual." ${ }^{\prime 89}$

The military asked the science fiction writer Bruce Sterling to observe the Defense Advanced Research Projects Agency's Battle of 73 Easting. Using mid1980s technology, a virtual war was conducted via network links. "What one really sees in '73 Easting' is something new and very strange: a complete and utter triumph of chilling, analytic cybernetic rationality over chaotic, real-life, human desperation." ${ }^{\prime 90}$ Sterling believes the military wants to extend itself into the virtual world. He expects requests for huge increases in military expenditures - a round of "cyberpork." "91

In an article entitled "Cyber-Deterrence," James Der Derian described the digital battlefield of Desert Hammer VI and the Advanced Warfighting Experiment. ${ }^{92}$ In a slick brochure entitled The Vision, he found a section called Exploit Modeling and Simulation. One particularly lively paragraph captures the spirit of military simulation: "Ten thousand linked simulators! Entire literal armies online, global real-time, broadband, fiberoptic, satellite-assisted, military simulation networking. And not just connected, not just simulated. Seamless." ${ }^{93}$ Der Derian was not surprised that the wording had been appropriated by the military from Bruce Sterling"s Wired article "War Is Virtual Hell."

Der Derian found scientists helping the protected species on the military base he visited. One of these species was the tortoise. The lengths to which the scientists went to protect the tortoise were analogous to the lengths to which the military 
will go to protect us. "The scientists claimed to be matching the warfighters chip for chip in the information war. Tortoises were tagged with transmitters, tracked by radio telemetry, and graphed in grid locations by computers. Landsat satellites were used to identify good habitat areas, aerial mine detection technology to find tortoises moving on the ground, and electronic sensors to warn off vehicles that might endanger the creatures." ${ }^{\prime 94}$

Many people are wondering what is happening. They are worried, but they are hopeful. Michael Heim believes we will experience an ontological shift, a shift in being: "An ontological shift is a change in the world under our feet, in the whole context in which our knowledge and awareness are rooted. Things change even before we become aware of what has been happening to us." ${ }^{\prime 95}$

Some people believe humans will change their opinions toward being and reality by adopting radical new attitudes; others are less hopeful. The physicist Max Planck did not think it possible for people to adapt to earthshaking changes of this magnitude. His specific point of reference was paradigm shifts in the sciences. Thomas Kuhn makes use of Planck's views in his classic The Structure of Scientific Revolutions: "A new scientific truth does not triumph by convincing its opponents and making them see the light, but rather because its opponents eventually die, and a new generation grows up that is familiar with it." ${ }^{\prime 96}$ If this cannot be avoided, we may miss an historic opportunity to contribute in a major way to an awe-inspiring shift in our humanity and our purpose. If we miss this opportunity and only grab onto the bytes and digits before us, we will not create a higher value-added philosophy of professional and institutional service. Instead, we will be in danger of placing ourselves on the margins of history. This does not mean that the functions librarians now perform will be discontinued but, rather, that machines will handle many of these functions and human intervention will be reduced to a minimum. In the March issue of $C \mathcal{E} R L$, the second part of this article will discuss some possibilities for creating the valueadded services and products that are essential for growth, success, and survival in the twenty-first century.

\section{Humans and Technology}

\section{My spring is past, my summer is over}

\section{Pushkin}

On the streets, it is assumed that humans are meaningfully free from the technologies surrounding them. Elsewhere, it is commonly accepted that humans are inseparable from these technologies. Bruce Mazlish believes the unwillingness of humans to recognize their underlying relationship to technology creates a discontinuity of significant proportions. ${ }^{97} \mathrm{In}$ his view, traditional attitudes about the humans and technology relationship must end.

\section{The discontinuity between humans and technology is of overwhelming interest because the nature of being (ontology) is at issue.}

In his article entitled "The Fourth Discontinuity," Mazlish reviewed Freud's observation that there have been three "ego-smashing" moments in the recent history of humanity: the Copernican revolution, in which the sun replaced the earth as the center of the universe; Darwin's theories of evolution, which "robbed man of his peculiar privilege of having been specially created, and relegated him to a descent from the animal world"; and Freud's own conclusion that the ego "is not even master in his own house." ${ }^{\prime 98}$ According to Mazlish, a fourth discontinuity still exists in our time. "It is the discontinuity between man and machine. In fact, my thesis is that this fourth discontinuity must now be eliminated-indeed, we have started on the task-and that in the process man's ego will have to undergo another rude shock." 99 
Eliminating this discontinuity is desirable, but the obstacles are tremendous. Rifkin believes the new computime "bears no relationship to the rhythms of nature." ${ }^{100}$ Robert Markley believes science will be the big winner in a return to the fixed structure theory of nature. "Cyberspace is the return of the Cartesian repressed in the age of semiotics," because what lies at the heart of cyberspace is the belief in "the mathematical structure of nature, in the computability of the universe." ${ }^{101}$ Others disagree. The structures and metaphors of biology, not mathematics, appear to best represent the underlying nature of cyberspace. For example, Freeman Dyson has found "the computer metaphor ... enormously fruitful as an aid to the understanding of living processes." ${ }^{\prime 102}$

The discontinuity between humans and technology is of overwhelming interest because the nature of being (ontology) is at issue. One senses that ignoring the problem will not be as easy as our response to earlier discontinuities. Millions walked away from the land into the city. Nature was left behind. Several hundred years ago, almost everyone was engaged in farming; today, almost no one is. Today, the economic base of the city continues to erode as the industrial sector shrinks and the service and information sectors grow. Brain over brawn. Mind over matter. The next step will be just as consequential-perhaps even more so.

Turkle sees people and machines in a new relationship in which one can be mistaken for the other. ${ }^{103}$ In chat rooms and other online communities, people of all ages assume roles quite different than their RL (real life): differences in gender, age, and species are not uncommon. Some cyber-events are disturbing, and the psychological impact on the individuals involved may approximate the intensity of real life. In March 1992, Ronald's MUD character Backlash found a way to control the actions of Elizabeth's character, Targa. Backlash 'forced' Targa to have sex with him. In this example of "virtual rape," Ronald directed the action and re- actions of the character Targa, independent of Elizabeth's desire as a player. ${ }^{104}$

Cyberville: Clicks, Culture, and the Creation of an Online Town is a more recent account of an online community. Author Stacy Horn created East Coast Hangout (Echo) "to meet guys." ${ }^{105}$ Bukatman summarized the significance of these innovations by depicting technologies "as extrusions of our organs and neural passages" 106 and terminal identity "as an essential cyborg formation, and a potentially subversive reconception of the subject that situates the human and the technological as coextensive, codependent, and mutually defining." 107

\section{Cyborg}

The union of cyberspace and the human organism has been most dramatically articulated in Donna Haraway's Cyborg Manifesto. ${ }^{108}$ Her language is uncompromising. "By the late twentieth century, our time, a mythic time, we are all chimeras, theorized and fabricated hybrids of machine and organism; in short, we are cyborgs. The cyborg is our ontology ... The cyborg is a condensed image both imagination and material reality." 109 Think of individuals as nodes on networks. ${ }^{110}$ Think mutated worlds. Do not think just ideas, think new flesh. ${ }^{111}$ "We're inside of what we make, and it's inside of us."112 Hari Kunzru described Haraway's world as "one of tangled networks-part human, part machine; complex hybrids of meat and metal that relegates old-fashioned concepts like natural and artificial to the archives."113

Haraway was excited about the future, optimistic. She foresaw a more equitable world as male-dominated institutions are replaced by those with universal, diverse values. Viviane Casimir also saw a new identity, "that of the borg," arising "in a postmodern culture, a world of reframing dichotomies ... a world of discontinuity and of contextualized truth and meaning, a new metaphysics, and a new hierarchy."114

Cyberspace is frequently framed in a context similar to the one used to depict 
ventures into space-moon shots and planetary explorations. Adventure, excitement, and the limitless are powerful inducements to support or to join. The power of the Saturn V has been replaced by the personal computer as the signifier of technological progress. ${ }^{115}$ David Tomas has suggested that cyberspace and the technologies surrounding it "constitute the central phase in a post-industrial 'rite of passage' between organically human and cyber-psychically digital life-forms as reconfigured through computer software systems." ${ }^{\prime 16}$

\section{Beyond Artificial Intelligence}

The possibility of intelligence emerging directly from computers rather than being programmed by humans is startling. The concept is simple. Humans will create artificial intelligence. Artificial intelligence(s) will create a new form of intelligence. This development might qualify as a new stage of evolution in the sense envisioned by Dyson. ${ }^{117}$ Below is a diagram of the flow created by this author to help visualize the sequence:

$$
\begin{aligned}
& \text { I } \rightarrow \text { A (I) } \rightarrow \text { A (i) } \rightarrow \square \\
& I=\text { Human intelligence } \\
& i=\text { Machine intelligence } \\
& \square=\text { Cyber-intelligence } \\
& \text { A = Artificial }
\end{aligned}
$$

Julian Dibbell believes that "someday the Net will be the summation of the world's total computing resources. All computers will link up into a chaotic digital soup in which everything is connected-indirectly or directly-to everything else. This coming net of distributed resources will be tremendously powerful, and tremendously hard to harness because of its decentralized nature. It will be an ecology of computing machines, and managing it will require an ecological approach." 118

He has suggested that "many of the most promising visions of how to coordinate the far-flung communication and computing cycles of this emerging platform converge on a controversial solu- tion: the use of self-replicators that roam the Net. Free-ranging, self-replicating programs, autonomous Net agents, digital organisms-whatever they are called, there's an old-fashioned word for them: computer viruses."119

At first, this prospect might be frightening. However, the biologist Lynn Margulis discovered that "most of the big steps in cellular evolution were caused by parasites."120 These parasites developed a symbiotic relationship with their hosts stronger and more adaptable than the cellular structure without this intervention. The computer virus is attractive because of its "irrepressible mobility," "self-centered autonomy," and "surprising agility."

Interest in the computer virus comes from three areas: (1) developers who want to harness "the power of self-replicating programs," (2) scientists who want to study "the abstract behavior of self-replicating codes," and (3) virus writers.

Mark Ludwig is a developer with a Ph.D. in physics from the University of Arizona. His first self-published book was The Little Black Book of Codes (1991). The detailed annotated source codes in his book led to the issuance of a legal injunction against its publication in France, which since has been lifted. In 1993, Ludwig published Computer Viruses, Artificial Life, and Evolution, which contains his Darwinian Genetic Mutation Engine. The programming utility "turns any normal DOS virus into a souped-up genetically evolving polymorph, complete with an option for sexual gene-swapping."121 It is described as a "finely tuned interaction of variety and natural selection that allows the environment itself to shape the internal code of the organisms dwelling in it."122

Tom Ray is an ecologist from the University of Delaware. He breeds viruses or worms, "software that is both self-reproducing and able to execute its code independent of any host program." ${ }^{\prime 123} \mathrm{He}$ wants to turn the Net into a jungle "infusing the vast unused spaces of the global computer networks with a roiling digital ecology as 
complex, as fascinating, and ultimately as beneficial to humankind as the rain forests that he has long sought to protect and understand." 124 Ray discovered that his socalled worms were bona fide parasitic viruses with surprising capabilities. The "tight-wound optimization" attained by these parasites would have confounded the "most wizardly" of software engineers. Yoked, these parasites might develop practical applications. Ray's plan to colonize the Net appears in "A Proposal to Create a Network-Wide Biodiversity Reserve for Digital Organisms," at ftp:/ /tierra.slhs.udel.edu/ tierra/doc/reserves.tex. ${ }^{125}$

Dibbell is thrilled by the potential opportunity to transform the Net "into the single most complex information entity since the emergence of the human brain." ${ }^{126}$ Intelligent agents with learning capabilities, self-replicating autonomous agents, free-flowing parasitic viruses borrowing and optimizing the reproductive codes of larger programs are spearheading efforts to create a new form of intelligence, a cyber-intelligence.

As mentioned earlier, this discussion will be continued in the March issue. Specifically, how will the four discontinuities impact our lives in the years ahead? What new developments might we expect? What can we do about them? How will these discontinuities impact the future of the library and the profession of librarianship? Naturally, this discussion will be speculative, although outlines and subtle patterns are visible on the horizon.

\section{Notes}

1. This is the judgment of Edward O. Wilson. "In contrast to widespread opinion, I believe that the Enlightenment thinkers of the seventeenth and eighteenth centuries got it mostly right. The assumptions they made about a lawful material world, the intrinsic unity of knowledge, and the potential for indefinite human progress are the ones we still take most readily to heart, suffer without, and find maximally rewarding as we learn more and more about the circumstances of our lives. Edward O. Wilson, "Back from Chaos," Atlantic Monthly 281, no. 3 (Mar. 1998): 41.

2. Encyclopaedia Britannica, $15^{\text {th }}$ ed., s.v. "philosophy, the history of the west."

3. Ibid.

4. Encyclopedia of Philosophy, 1972: reprint, s.v. "positivism."

5. Ibid.

6. Ibid.

7. Gary P. Radford, "Positivism, Foucault, and the Fantasia of the Library: Conceptions of Knowledge and the Modern Library Experience," Library Quarterly 62, no. 3 (Oct. 1992): 408-24; John M. Budd, "An Epistemological Foundation for Library and Information Science," Library Quarterly 65, no. 3 (July 1995): 296-318; Archie Dick, "Library and Information Science as a Social Science: Neutral and Normative Conceptions," Library Quarterly 65, no. 2 (Apr. 1995): 216-35.

8. Gary P. Radford and John M. Budd, "We Do Not Need a Philosophy of Library and Information Science-We're Not Confused Enough: A Response to Zwaldo," Library Quarterly 67, no. 3 (July 1997): 315. Online. Expanded Academic ASAP.

9. Budd, "An Epistemological Foundation for Library and Information Science," 315.

10. One exception is Jim Zwaldo's "We Don't Need a Philosophy of Library and Information Science-We're Confused Enough Already," Library Quarterly 67, no. 2 (Apr. 1997): 103-21.

11. The author assumes that the observations of Radford, Budd, and Dick address services and products, but not the ALA's Code of Professional Ethics in the areas of censorship, privacy, due process, and equality of opportunity.

12. Wilson, "Back from Chaos," 62.

13. Ibid.

14. Frederick Turner, Beyond Geography: The Western Spirit against the Wilderness

(New York: Viking, 1980), 14-15.

15. Peter Hoeg, Smilla's Sense of Snow, trans. Tiina Nunnally (New York: Farrar Straus and Giroux, 1993), 189.

16. Morris Berman, Coming to Our Senses: Body and Spirit in the Hidden History of the West (New York: Bantam, 1990), 179.

17. Andrew Odlyzko, "Silicon Dreams and Silicon Bricks: The Continuing Evolution of Li- 
braries," Library Trends 46, no. 1 (summer 1997): 154.

18 Marguerite Holloway, “A New Classic," University Business (May/June 1998): 36. Holloway writes about James J. O'Donnell and his most recent book, Avatars of the Word: From Papyrus to Cyberspace (Cambridge, Mass.: Harvard Univ. Pr., 1998).

19. Odlyzko, "'Silicon Dreams and Silicon Bricks," 153.

20. Tom McArthur states that "the structuring of books ...took all of 4,000 years to bring about." Worlds of Reference: Lexicography, Learning, and Language from the Clay Tablet to the Computer (New York: Cambridge Univ. Pr., 1986), 69.

21. Richard Bode, First You Have to Row a Little Boat: Reflections on Life and Living (New York: Warner, 1993), 191.

22. George Orwell, Nineteen Eighty-Four (New York: Harcourt, Brace, 1949), 14.

23. Zwaldo, "We Don't Need a Philosophy of Library and Information Science."

24. Michael K. Buckland, Library Services in Theory and Context, $2^{\text {nd }}$ ed. (New York: Pergamon Pr., 1988), 16.

25. Two major journals have published special issues in the past four years with titles linking books, buildings, and bytes: "Books, Bricks, \& Bytes," Daedalus 125, no. 4 (fall 1996); and "Buildings, Books, and Bytes: Perspectives on the Benton Foundation Report on Libraries in the Digital Age," Library Trends 46, no. 1 (summer 1997).

26. Excerpt from the poem "Beneath Winter's Roof," by Ekaterina Iosifova, in Clay and

Star: Contemporary Bulgarian Poets, trans. and ed. Lisa Sapinkopf and Georgi Belev (Minneapolis, Minn.: Milkweed, 1992), 133.

27. Excerpt from the poem "Choruses from 'The Rock,'" by T. S. Eliot, in Collected

Poems 1909-1962 (New York: Harcourt Brace Jovanovich, 1970), 147.

28. Excerpt from the poem "The Mirror's Hide and Seek," by Liliana Ursu, in The Sky Behind the Forest: Selected Poems, trans. Liliana Ursu with Adam J. Sorkin and Tess Gallagher (Newcastle upon Tyne: Bloodaxe Bks., 1997), 46. 1987).

29. Jeremy Rifkin, Time Wars: The Primary Conflict in Human History (New York: Henry Holt,

30. Ibid., 69-70.

31. Robert Doisneau, Three Seconds of Eternity (New York: te Neues Pub., 1997).

32. Tracy Kidder, The Soul of the New Machine (Boston: Little Brown, 1981), 137.

33. Scott Bukatman, Terminal Identity: The Virtual Subject in Postmodern Science Fiction (Durham: Duke Univ. Pr., 1993), 109.

34. Rifkin, Time Wars, 155.

35. Bukatman, Terminal Identity, 108.

36. Lance Olsen, "Virtual Termites: A Hypotextual Technomutant Explo(it)ration of William Gibson and the Electronic Beyond(s)," Style 29, no. 2 (summer 1995): 300.

37. James S. Russell, "The Way We Work," Architectural Record 186, no. 6 (June 1998): 139.

38. William Gibson, Neuromancer (New York: Berkeley, 1984), 51.

39. Larry McCaffery, "An Interview with William Gibson," Storming the Reality Studio: A Casebook of Cyberpunk and Postmodern Fiction (Durham, N.C.: Duke Univ. Pr., 1991), 272.

40. Marie-Laure Ryan, "Introduction: From Possible Worlds to Virtual Reality," Style 29, no. 2 (summer 1995): 178.

41. Frances Cairncross, The Death of Distance: How the Communication Revolution Will Change Our Lives (Cambridge, Mass.: Harvard Univ. Pr., 1998).

42. Margot Lovejoy, Postmodern Currents: Arts and Artists in the Age of Electronic Media (Ann Arbor, Mich.: UMI, 1989), 247-48. Thomas M. Disch extends Lovejoy's observations in his analysis of the impact of science fiction on society. The Dreams Our Stuff Is Made Of: How Science Fiction Conquered the World (New York: Free Pr., 1998).

43. William Gibson, Virtual Light (New York: Bantam Bks., 1993); —, Idoru (New York: Putnam, 1996).

44. Bukatman, Terminal Identity, 108.

45. Ibid., 156.

46. Disch, The Dreams Our Stuff Is Made Of.

47. Ronald Schmitt, "Mythology and Technology: The Novels of William Gibson," Extrapolation 34, no. 1 (spring 1993): 75-76.

48. Edward S. Casey, "Smooth Spaces and Rough-Edged Places: The Hidden History of Place," Review of Metaphysics 51, no. 2 (Dec. 1997): 287.

49. Ibid.

50. Ibid., 293.

51. Ibid., 292.

52. Encyclopedia of Philosophy, s.v. "positivism."

53. Bukatman, Terminal Identity, 250. 
54. Ibid.

55. Silvio Gaggi, From Text to Hypertext: Decentering the Subject in Fiction, Film, the Visual Arts, and Electronic Media (Philadelphia: Univ. of Pennsylvania Pr., 1997), 115. See also the special issue of Modern Fiction Studies 43, no. 3 (fall 1997) on the subject of "Technocriticism and Hypernarrative."

56. Bukatman, Terminal Identity, 208.

57. Fredric Jameson, Postmodernism, or the Cultural Logic of Late Capitalism (Durham, N.C.: Duke Univ. Pr., 1991), 44.

58. Sherry Turkle, Psychoanalytic Politics: Freud's French Revolution (New York: Basic Bks., 1977), 139.

59. Vivian Sobchack, "The Scene on the Screen: Towards a Phenomenology of Cinematic and Electronic Presence," Post-Script 10 (1990): 56.

60. Steven D. Spark, Glued to the Set : The 60 Television Shows and Events That Made Us Who We Are Today (New York: Simon and Schuster, 1997).

61. Sherry Turkle, Life on the Screen: Identity in the Age of the Internet (New York: Simon \& Schuster, 1995), 20.

62. Freeman Dyson, Infinite in All Directions (New York: Harper \& Row, 1988), 9. Gifford Lectures given at Aberdeen, Scotland, Apr.-Nov. 1985.

63. Bukatman, Terminal Identity, 270.

64. Lisa Mason, Arachne (New York: Morrow, 1990), 70-71.

65. Hans Moravec, "Pigs in Cyberspace," Thinking Robots, an Aware Internet, and Cyberpunk Librarians, ed. R. Bruce Miller and Milton T. Wolf (Chicago: ALA, 1992), 15.

66. Berman, Coming to Our Senses, 109.

67. Wilson, "Back from Chaos," 62.

68. Jack G. Voller, "Neuromanticism: Cyberspace and the Sublime," Extrapolation 34, no. 1 (spring 1993): 22.

69. Vaclav Havel, "The Need for Transcendence in the Postmodern World" (speech given at Independence Hall, Philadelphia, 4 July 1994).

70. Turkle, Psychoanalytic Politics, 41.

71. Berman, Coming to Our Senses, 79-80.

72. Thomas M. Disch, "Double Talk, Double Dutch, Dutch Chocolate," Hudson Review 51, no. 1 (spring 1998): 233.

73. Mohamed Zayani, "Review Essay: The Deterritorialization of Capitalism in an Age of Punctuated Equilibrium: Globalism, Tribalism, and Other Related Matters," Studies in the Humanities 24, nos. 1-2 (June-Dec. 1997): 101.

74. Jean Baudrillard, Simulations, trans. Paul Foss, Paul Patton, and Philip Beitchman, Foreign Agents Series, ed. Jim Fleming and Sylvere Lotringer (New York: Semiotext[e], 1983), 11-12.

75. Guy Debord, Society of the Spectacle (Detroit: Black \& Red, 1983).

76. .Jean Baudrillard, In the Shadow of the Silent Majorities, trans. Paul Foss, Paul Payton, and John Johnston, Foreign Agents Series, ed. Jim Fleming and Sylvere Lotringer (New York: Semiotext[e], 1983), 101.

77. Spark, Glued to the Set, 4.

78. Baudrillard, In the Shadow of the Silent Majorities, 21.

79. Michael Oreskes, "America's Politics Loses Way as Its Vision Changes World," New York Times, 18 Mar. 1990, 22.

80. Alvin Toffler, Future Shock (New York: Bantam Bks., 1971), 161.

81. Turkle, Life on the Screen, 10.

82. Ibid., 11.

83. Ibid., 14 .

84. Ibid., 45 .

85. Gary Taubes, "Surgery in Cyberspace," Discover 15, no. 12 (Dec. 1994): 86.

86. Ibid., 85 .

87. Michael Dertouzos, What Will Be: How the New World of Information Will Change Our Lives

(San Francisco: Harper Collins, 1998), 165.

88. Ibid., 172-74.

89. Ibid., 94 .

90. Bruce Sterling, "War Is Virtual Hell," Wired 1, no. 1 (Jan. 1994): 46.

91. Ibid.

92. James Der Derian, “Cyber-Deterrence," Wired 2, no. 9 (Sept. 1994). 6 pp. Online. Internet. 7 July 1998. Available: http:/ /www.ucet.ufl.edu/ bruegg/ cyber.deter.html.

93. Ibid., 5.

94. Ibid., 5 .

95. Michael Heim, The Metaphysics of Virtual Reality (New York: Oxford Univ. Pr., 1993), xiii. 
96. Thomas Kuhn, The Structure of Scientific Revolutions, $2^{\text {nd }}$ ed. rev. (Chicago: Univ. of Chicago Pr., 1972), 151.

97. Bruce Mazlish, "The Fourth Discontinuity," in Technology and Culture, ed. Melvin Kranzberg and William Davenport (New York: Schocken Bks., 1972), 217-18.

98. Ibid. Quote by Sigmund Freud is from his eighteenth lecture in The Complete Introductory Lectures on Psychoanalysis, trans. James Strachey (New York: Norton, 1966), 284-85.

99. Ibid.

100. Rifkin, Time Wars, 119.

101. Robert Markley, "Boundaries: Mathematics, Alienation, and the Metaphysics of Cyberspace," Configurations 2 (fall 1994): 488.

102. Dyson, Infinite in All Directions, 56.

103. Turkle, Life on the Screen, 17.

104. Julian Dibbell, "Rape in Cyberspace," Village Voice, 21Dec. 1993, 38.

105. Harold Goldberg, review of Cyberville: Clicks, Culture, and the Creation of an Online Town, by Stacy Horn, New York Times Book Review, 15 Feb. 1998, 13.

106. Bukatman, Terminal Identity, 71.

107. Ibid., 22.

108. Donna Haraway, "Cyborg Manifesto: Science, Technology, and Socialist-Feminism in the Late Twentieth Century," in Donna Haraway, Simians, Cyborgs, and Women: The Reinvention of Nature (New York: Routledge, 1991), 149-81.

109. Ibid., 150.

110. Hari Kunzru, “You Are Borg," Wired 5, no. 2 (Feb. 1997): 156.

111. Ibid., 157.

112. Ibid., 209.

113. Ibid., 157.

114. Viviane Casimir, "Data and Dick's Deckard: Cyborg as Problematic Signifier," Extrapolation 38, no. 4 (winter 1997): 278.

115. Bukatman, Terminal Identity, 6-7.

116. David Tomas, “Old Rituals for New Space: 'Rites of Passage' and William Gibson's Cultural Model of Cyberspace," in Cyberspace: First Steps, ed. Michael Benedikt (Cambridge: MIT Pr., 1991), 33.

117. Dyson, Infinite in All Directions, 9.

118. Julian Dibbell, "Viruses Are Good for You," Wired 3, no. 2 (Feb. 1995). 15 pp. Online. Internet. 7 July 1998. Available: http:/ / www.ucet.ufl.edu/ bruegg/ viruses.html, 1.

119. Ibid.

120. Dyson, Infinite in All Directions, 69; citing Lynn Margulis, Symbiosis in Cell Evolution.

121. Dibbell, "Viruses Are Good for You," 7.

122. Ibid.

123. Ibid., 8 .

124. Ibid., 8 .

125. Ibid., 10.

126. Ibid., 13. 